RESEARCH ARTICLE

\title{
PHARMACOLOGICAL INVESTIGATION ON METHANOLIC EXTRACT OF LEAVES OF Diospyros peregrina GURKE ON ALLOXAN INDUCED HYPERGLYCEMIA IN RATS
}

\author{
*Pawan $\mathrm{K}^{1}$, Goswami $\mathrm{DV}^{1}$, Jain $\mathrm{SK}^{2}$, Prajapati $\mathrm{N}^{3}$ \\ ${ }^{1}$ Smt. Vidyawati College of pharmacy, Jhansi (UP) 284001 INDIA \\ ${ }^{2}$ Institute of Pharmacy, Bundelkhand University, Jhansi (U.P.), 284001 INDIA \\ ${ }^{3}$ Shri Ram Nath Singh institute of pharmaceutical sciences \& technology, Sitholi, Gwalior (M.P.) INDIA \\ *Corresponding Author's Email: pawandhakar2008@gmail.com
}

Received 28 Sep 2011; Revised 14, 19 Oct 2011; Accepted 20 Oct 2011, Available online 26 Oct 2011

\begin{abstract}
Diospyros peregrina, commonly known as Kalatendu, is widely used in different parts of India for the treatment of diabetes mellitus. The present study was designed to evaluate the antihyperglycemic effect of a methanolic extract of Diospyros peregrina leaves (DPLE) in alloxan diabetic rats. Hyperglycemia was induced by single intravenous injection of alloxan (70mg/kg body weight). The extract was administered orally at a dose of 100,200 and $400 \mathrm{mg} / \mathrm{kg}$ body weight, to normal and alloxan diabetic rats. No effect of the extract was observed in normal rats. Significant effect of the extract was observed in alloxan diabetic rats. Metformin was the reference drug used in the experiments. Glucose tolerance test was also performed. The studies indicate that the crude extract exhibited statistically significant antihyperglycemic activities in glucose tolerance test and alloxan induced diabetic rats.
\end{abstract}

Kevwords: Diosnvros neregrina. Methanolic extract. Antihvnerolvcemic activitv

\section{INTRODUCTION}

Diabetes mellitus is a very common chronic disease. Although both genetic \& environmental factors appear to play a role, the cause of diabetes mellitus is still not clear. A large number of studies have demonstrated that oxidative stress \& nonenzymatic protein glycation are closely associated with the development of diabetes mellitus ${ }^{(1,2)}$. Diabetes mellitus is a heterogeneous metabolic disorder characterized by altered carbohydrate, lipid \& protein metabolism ${ }^{(3)}$. Diospyros peregrina (Ebenaceae) is a small middle sized tree, glabrous except the younger parts with numerous spreading branches, forming an impenetrable shady head, which grows luxuriantly in the plains of coastal west Bengal. Ripe fruits are edible with ethnomedicinal significance as tonics \& aphrodisiac ${ }^{(4)}$. The plant Diospyros peregrine belonging to family Ebenaceae , known as Gab \& Kalatendu in vernacular has been used as an antidiarrhoeal, aphrodisiac, anti snake bite \& as a tonic in the ancient Indian medicine ${ }^{(5)}$. Diospyros peregrine (syn. Malabanica Desr, D. embryopteris pers.) or family Ebanaceae is a well known medicinal plant, the bark of which is used in the treatment of dysentery \& intermittent fevers ${ }^{(6,7)}$.

\section{MATERIALS AND METHODS}

\section{Plant Material}

The leaves of Diospyros peregrina Gurke were collected from Forest Research Institute garden, Dehradun, India, in month of October 2008. The identification of the plant was verified by Dr. P. B. Singh, Scientist and Head of Regional Research Institute (Ay.), Jhansi. A voucher specimen (Accession no. 401) of the authenticated Diospyros peregrina Gurke has been deposited in the herbarium of the Institute.

\section{Drugs and Chemicals}

Alloxan Hydrate (ALX) was purchased from $\mathrm{CDH}$ Chemicals (New Delhi, India), while Metformin Hydrochloride (MET) was a gift sample from PDP Ltd.[Indore (M.P.), India]. Glucose Oxidase Peroxidase glucose estimate kit was purchased from (Span Diagnostic Ltd., Surat, India). All remaining chemicals used in the experiment were of highest grade commercially available.

\section{Animals}

Healthy adult albino rats of Wistar strain weighing about $150-200 \mathrm{~g}$ of either sex between 2-3 months of age were selected as the animal model. Female Swiss mice (20-25g) were used for acute toxicity studies. They were housed in group in polypropylene cages, maintained under standard conditions (12:12h light: dark cycle; $25 \pm 3^{\circ} \mathrm{C} ; 40-60 \%$ humidity) and maintained with free access to standard rat pellet diet (Hindustan Lever Ltd., Mumbai, India) and water made available ad libitum. Eighteen hours before experimentation, food was withdrawn but water remained ad libitum. All experimental protocols were approved by Institutional Animal Ethical committee of the Institute (approved by CPCSEA Regd. No. 716/02/a/CPCSEA).

\section{Acute toxicity Study}

Healthy female swiss mice, starved 3-4 hours were subjected to acute toxicity studies to determine the safe dose by acute toxic class method of oral toxicity as per OECD 423 guidelines $^{(8)}$. Different dose level of 5, 50, 300, $2000 \mathrm{mg}$, the mice were observed continuously for 2 hours for behavioural, neurological and autonomic profile and, after a period of 24 and 72 hours, for any lethality, moribund state or death. No death was observed at highest dose. The doses selected were 100, 200 and $400 \mathrm{mg} / \mathrm{kg}$. 


\section{Assessment of serum glucose}

Serum glucose was estimated in overnight fasted rats 48 hour after the administration of alloxan. Blood was withdrawn from the retro orbital plexus on $0,1,2$, and 3 hour after administration of the DPLE and clear serum were obtained after centrifugation at $3000 \mathrm{rpm}$ for 10 minutes. Fasting serum glucose level was estimated using a Glucose Oxidase - Peroxidase glucose estimate kit (Span Diagnostic Ltd., Surat, India) ${ }^{(9)}$.

\section{EXPERIMENTAL PROCEDURE}

\section{Effect of DPLE on blood glucose in normal rats:}

The Swiss albino Wistar rats were divided into five different groups of six animals in each group. Rats were fasted overnight (18 hour) and optimum care was exercised to avoid coprophagia. Vehicle treated group received $0.5 \%$ Sodium CMC in distilled water while extract treated group received DPLE 100, 200, $400 \mathrm{mg} / \mathrm{kg}$ intragastrically, while standard treated group received metformin $500 \mathrm{mg} / \mathrm{kg}$ intragastrically. The assessment of blood glucose was carried out on $0,1,2$, and 3 hour after administration of drug.

\section{Effect of DPLE on oral glucose tolerance test (OGTT)} in normal rats :

The oral glucose tolerance test ${ }^{(10)}$ was performed in overnight fasted (18 hour) normal rats. Rats were divided into five different groups of six animals in each group. Group-I received glucose $(4 \mathrm{~g} / \mathrm{kg})$ and vehicle. Group-II received glucose $(4 \mathrm{~g} / \mathrm{kg})$ and DPLE $100 \mathrm{mg} / \mathrm{kg}$. Group-III received glucose $(4 \mathrm{~g} / \mathrm{kg})$ and DPLE $200 \mathrm{mg} / \mathrm{kg}$. Group-IV received glucose $(4 \mathrm{~g} / \mathrm{kg})$ and DPLE $400 \mathrm{mg} / \mathrm{kg}$. Group-V received glucose $(4 \mathrm{~g} / \mathrm{kg})$ and metformin $(500 \mathrm{mg} / \mathrm{kg})$. Glucose fed orally. Blood was withdrawn from the retro orbital plexus ${ }^{(11)}$ at $0,30,60$ and 120 minutes after glucose administration and the serum was estimated for fasting glucose level.

\section{Effect of DPLE on alloxan-induced hyperglycaemia:}

The Swiss albino Wistar rats were divided into six different groups of six animals. Rats were fasted overnight and optimum care was exercised to avoid caprophagia. Non diabetic control group received normal saline while diabetic control group received alloxan and vehicle of the extract. Extract treated groups received DPLE (100, 200 and $400 \mathrm{mg} / \mathrm{kg}$, intragastrically) in addition to alloxan. Standard treated group received metformin $(500 \mathrm{mg} / \mathrm{kg}$, intragastrically). The assessment of blood glucose was carried out on $0,1,2$ and 3 hour after administration of drug.

\section{Statistical Analysis}

The data were analyzed with ANOVA by using Dunnett multiple comparision test and significance was calculated.

\section{RESULTS}

\section{Acute toxicity Study}

Acute toxicity studies revealed that extract was safe up to dose level of $2000 \mathrm{mg} / \mathrm{kg}$ of body weight (limit test). No lethality or any toxic reactions or morbidity state were observed up to the end of the study period.

Table 1: Effect of DPLE on Normal glycemic rats

\begin{tabular}{|c|c|c|c|c|}
\hline \multirow{3}{*}{ Groups } & \multicolumn{4}{|c|}{ Serum glucose level (mg/dl) } \\
\hline & \multicolumn{4}{|c|}{ TIME } \\
\hline & $\mathbf{0 h}$ & 1h & $2 \mathrm{~h}$ & $3 \mathbf{h}$ \\
\hline $\begin{array}{l}\text { Group I } \\
\text { Vehicle }\end{array}$ & $76.44 \pm 1.63$ & $84.25 \pm 2.21$ & $82.83 \pm 2.50$ & $78.86 \pm 2.13$ \\
\hline $\begin{array}{l}\text { Group II } \\
\text { DPLE } 100\end{array}$ & $76.44 \pm 1.63$ & $85.52 \pm 1.54$ & $84.53 \pm 1.88$ & $86.23 \pm 1.80$ \\
\hline $\begin{array}{l}\text { Group III } \\
\text { DPLE } 200\end{array}$ & $78.43 \pm 3.08$ & $79.42 \pm 2.61$ & $77.44 \pm 2.11$ & $80.56 \pm 2.38$ \\
\hline $\begin{array}{l}\text { Group IV } \\
\text { DPLE } 400\end{array}$ & $74.17 \pm 3.01$ & $75.31 \pm 1.86$ & $77.44 \pm 2.88$ & $79.62 \pm 2.01$ \\
\hline $\begin{array}{l}\text { Group V } \\
\text { Metformin }\end{array}$ & $82.26 \pm 3.01$ & $80.70 \pm 2.38$ & $79.28 \pm 3.21$ & $79.14 \pm 3.14$ \\
\hline
\end{tabular}

Values are expressed as mean \pm SEM, $(\mathrm{n}=6), \quad * \mathrm{P}<0.05$, compared to vehicle treated group (group I) (Dunnett multiple comparison test).

\section{Alloxan-induced Hyperglycaemia:}

The single intravenous dose of alloxan induced significant hyperglycaemia in 48 hours of treatment in the experimental rats which was confirmed by the presence of high serum glucose level (>200 mg/dl). The rats exhibiting serum glucose level less than $200 \mathrm{mg} / \mathrm{dl}$ at 0 hour were excluded from the study.

\section{Effect of DPLE on blood glucose in Normal Rats}

One way ANOVA did not show any significant effect of DPLE on blood glucose level in normal rats. Neither extract nor the standard of metformin ( $\mathrm{P}>0.05)$ significantly affects serum glucose level (table 1).

\section{Effect DPLE on Oral Glucose Tolerance Test (OGGT)}

One way ANOVA showed significant effect of DPLE on OGGT. Dunnett multiple comparison test indicated that DPLE $(100,200$ and $400 \mathrm{mg} / \mathrm{kg})$ exhibited a significant reduction in serum glucose level from up to 120 minutes after glucose load and the effect was comparable to that of standard antidiabetic drug metformin (table 2). 


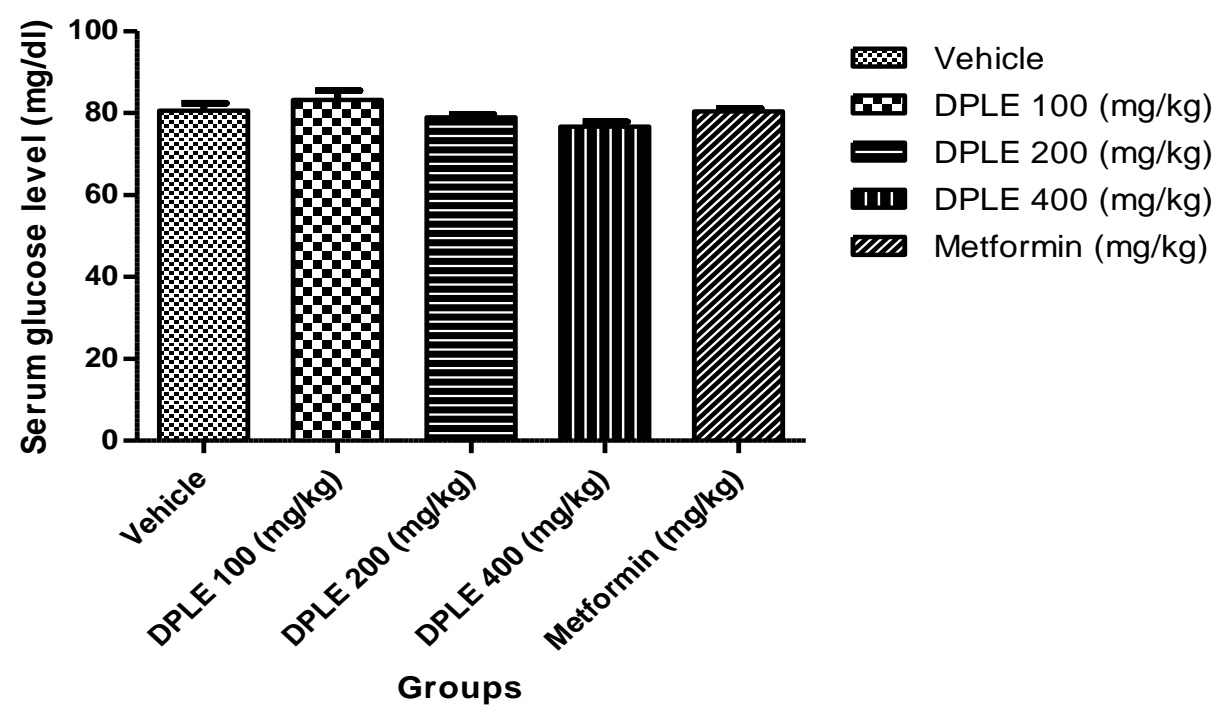

Figure 1: Graphical representation of DPLE on Normal glycemic rats

Table 2: Effect of DPLE on oral glucose tolerance test

\begin{tabular}{|c|c|c|c|c|}
\hline \multirow{3}{*}{ Groups } & \multicolumn{4}{|c|}{ Serum glucose level (mg/dl) } \\
\hline & \multicolumn{4}{|c|}{ TIME } \\
\hline & Omin & 30min & $60 \mathrm{~min}$ & $120 \mathrm{~min}$ \\
\hline $\begin{array}{l}\text { Group I } \\
\text { Vehicle }\end{array}$ & $81.67 \pm 3.48$ & $156.97 \pm 3.54$ & $149.07 \pm 2.96$ & $110.08 \pm 2.74$ \\
\hline $\begin{array}{l}\text { Group II } \\
\text { DPLE } 100\end{array}$ & $72.93 \pm 1.99$ & $132.30 \pm 3.03 * *$ & $123.35 \pm 4.16^{* *}$ & $105.34 \pm 2.78^{*}$ \\
\hline $\begin{array}{l}\text { Group III } \\
\text { DPLE } 200\end{array}$ & $75.79 \pm 2.89$ & $125.25 \pm 2.91 * *$ & $110.55 \pm 3.11^{* *}$ & $92.59 \pm 2.26^{*}$ \\
\hline $\begin{array}{l}\text { Group IV } \\
\text { DPLE } 400\end{array}$ & $71.25 \pm 2.78$ & $113.31 \pm 3.47 * *$ & $91.43 \pm 3.79 * *$ & $83.69 \pm 6.34 * *$ \\
\hline $\begin{array}{l}\text { Group V } \\
\text { Metformin }\end{array}$ & $66.38 \pm 3.06^{*}$ & $109.07 \pm 2.70 * *$ & $82.68 \pm 1.54 * *$ & $74.11 \pm 1.53 * *$ \\
\hline
\end{tabular}

Values are expressed as mean \pm SEM, $(\mathrm{n}=6)$,

$* \mathrm{P}<0.05$ as compared to vehicle treated group (Group I), **P $<0.01$ compared to vehicle treated group (Group I) (Dunnett multiple comparison test).
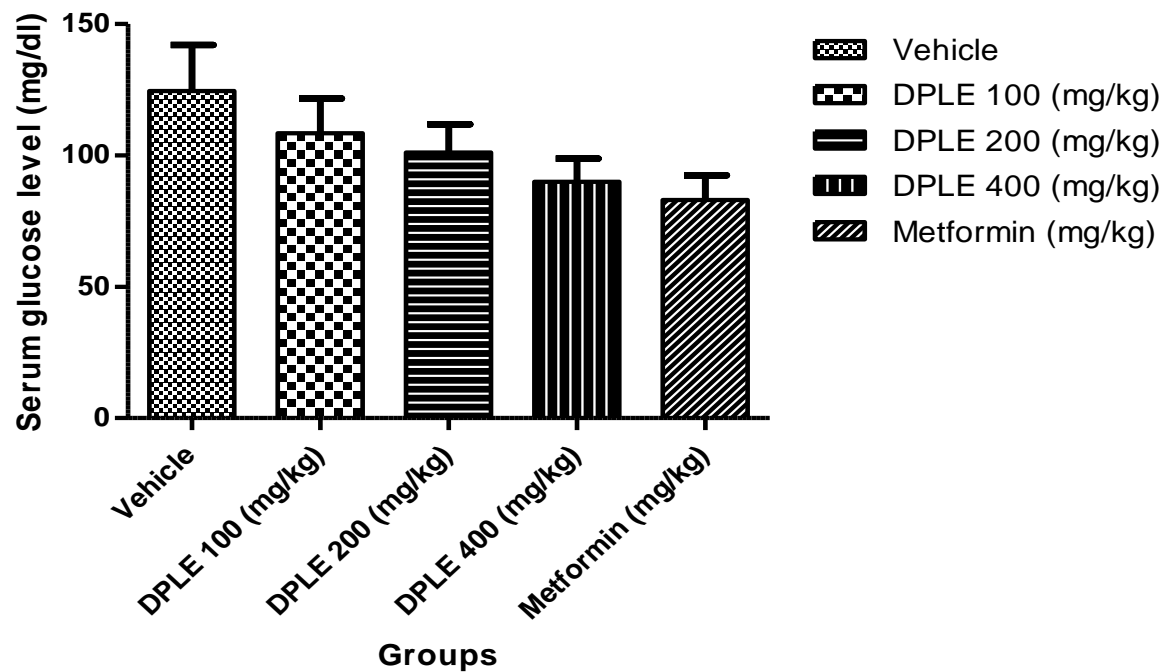

Figure 2: Graphical representation of DPLE on oral glucose tolerance test 


\section{Effect of DPLE on Alloxan induced Hyperglycaemia in Rats}

One way ANOVA showed significant effect of DPLE on alloxan induced hyperglycaemia in rats. Dunnett multiple comparison test indicated that DPLE (100, 200 and $400 \mathrm{mg} / \mathrm{kg})$ exhibited a significant reduction in the hyperglycaemia in alloxan treated animals. The effect of DPLE was comparable to that of standard drug metformin (Table 3).

Table 3: Effect of DPLE on alloxan induced hyperglycaemia in rats

\begin{tabular}{|c|c|c|c|c|}
\hline \multirow{3}{*}{ Groups } & \multicolumn{4}{|c|}{ Serum glucose level (mg/dl) } \\
\hline & \multicolumn{4}{|c|}{ TIME } \\
\hline & $\mathbf{0 h}$ & $1 \mathrm{~h}$ & $2 \mathbf{h}$ & $3 \mathbf{h}$ \\
\hline $\begin{array}{l}\text { Group I } \\
\text { NC }\end{array}$ & $81.56 \pm 3.14$ & $79.12 \pm 2.14$ & $80.89 \pm 3.45$ & $80.34 \pm 3.45$ \\
\hline $\begin{array}{l}\text { Group II } \\
\text { DC }\end{array}$ & $357.20 \pm 2.16$ & $355.32 \pm 2.68$ & $351.41 \pm 1.99$ & $356.74 \pm 2.95$ \\
\hline $\begin{array}{l}\text { Group III } \\
\text { DPLE } 100\end{array}$ & $352.43 \pm 2.83$ & $341.18 \pm 2.51 * *$ & $330.21 \pm 2.23 * *$ & $321.13 \pm 2.68 * *$ \\
\hline $\begin{array}{l}\text { Group IV } \\
\text { DPLE } 200\end{array}$ & $348.68 \pm 3.63$ & $323.68 \pm 3.50 * *$ & $307.30 \pm 2.82 * *$ & $289.99 \pm 2.80 * *$ \\
\hline $\begin{array}{l}\text { Group V } \\
\text { DPLE } 400\end{array}$ & $342.27 \pm 2.91$ & $297.55 \pm 3.40 * *$ & $259.48 \pm 4.54 * *$ & $227.90 \pm 3.79 * *$ \\
\hline $\begin{array}{l}\text { Group VI } \\
\text { Metformin }\end{array}$ & $354.19 \pm 2.85$ & $280.45 \pm 2.97 * *$ & $212.58 \pm 3.81 * *$ & $190.56 \pm 4.92 * *$ \\
\hline
\end{tabular}

$\mathrm{NC}=$ Normal Control

DC $=$ Diabetic Control

Values are expressed as mean \pm SEM, $(n=6)$,

$* \mathrm{P}<0.05$ as compared to vehicle treated group (Group II), **P<0.01 compared to vehicle treated group (Group II)

(Dunnett multiple comparison test).

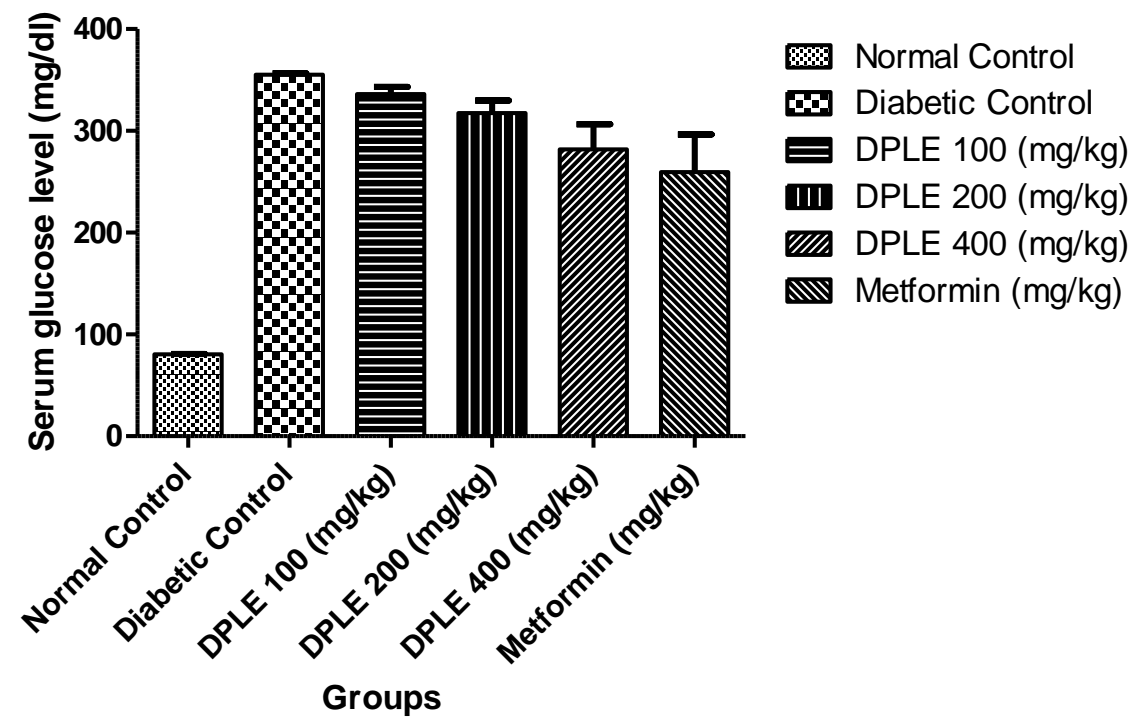

\section{DISCUSSION}

Figure 3: Graphical representation of DPLE on alloxan induced hyperglycaemia in rats

Currently available drug regimen for management of diabetes mellitus has certain drawback ${ }^{(12,13)}$ and therefore, there is need for safer more effective anti- diabetic drugs. This study was therefore undertaken to assess antihyperglycaemic properties of Diospyros peregrina plant, which have been reported in Ayurveda to be useful in diabetes mellitus. It is well documented that alloxan induce diabetes by damaging the insulin secreting cells of the pancreas leading to hyperglycaemia ${ }^{(14)}$. Excessive hepatic glycogenolysis and gluconeogenesis associated with decreased utilization of glucose by tissues in the fundamental mechanism underlying hyperglycaemia in the diabetic state ${ }^{(15)}$. The difference observed between the initial and final fasting serum glucose levels of different groups in the present investigations revealed a significant elevation in blood glucose in the diabetic control (ALX treated) group as compared with normal animals at the end of the 48 hours after ALX administration. In our study, 
treatment with a single dose of the methanolic leaves extract of Diospyros peregrina did not showed any significantly decrease in the basal glucose level in normal rats. Also like the extract, metformin did not affect the serum level. This is in accordance with the reports which demonstrated that metformin does not produce hypoglycaemia in non-diabetic state.

In glucose loaded normal rats, hypoglycaemia was observed at 120 minutes after administration of the DPLE. This indicates the efficacy of the extract to control elevated blood sugar. Since alloxan selectively destroy $\beta$-cells of pancreas, we would accept the extract to exert no effect on serum glucose concentration in alloxan diabetic rats if the mode of action is mediated through insulin production. Therefore, the present results suggest that the hypoglycaemic effect observed with DPLE appear to involve mechanism that does not involve insulin.

The results further revealed maintenance of blood sugar levels in diabetic rats after single dose administration of DPLE throughout the period of study. Metformin, used as the reference oral hypoglycaemic agent in this study, is a biguanide. Generally, the exact mechanism of action of biguanides is not clearly understood. Currently, proposed mechanism of action include : (1) direct stimulation of glycolysis in tissues, with increased glucose removal from

\section{REFERENCES}

1. Nawrath PP, Bierhus A, Vogel GE. Non enzymatic glycation \& oxidative stress in chronic illnesses \& diabetes mellitus, Medklin, 1999, 94, 29-30.

2. Vlassara H, Palace MR, Diabetes \& advanced glycation endoproducts, J Intern Med. 2002, 251(2):87-101

3. Das AV, Padayutti PS, Paulose CS, Effect of leaf extract of Aegle marmelose (L) Crrea ex Roxb on histological \& ultrastructural changes in tissues of streptozotocin induced diabetic rats, Indian J Exp Biol. 1996, 34(4):341-5.

4. Kirtikar KR, Basu BD, Singh B, Singh MP, Indian Medicinal Plants, Reprint Edition, In: Dehradun, 2nd Edition, 1975, 1502-1525.

5. Kirtikar K R and BASU B D, Basu L M, Indian Medicinal plants, $2^{\text {nd }}$ Edition, 1933, 1502.

6. Chopra R N, Nayar S L and Chopra I C, Glossary of Indian Medicinal Plants, CSIR, New Delhi, 1956, 99

7. Kirtikar K R and Basu B D, Indian medicinal Plants, $2^{\text {nd }}$ Edition, 1935, 1503.

8. OECD Guideline for testing of chemicals, Acute Oral Toxicity-Acute Toxic Class Method, 2001, 423, 1.

9. Trinder P, Determinition of blood glucose using 4Aminophenzon as oxygen acceptor, J Clin Pathol, 1969, 22, 246

10. Zanatta L, Sousa E, Cazarolli L H, Junior L H, Pizzolatti M G, Szpoganicz B, Effect of crude extract and fraction from Vitex megapotamica leaves on hyperglycemia in alloxan diabetic rats, J Ethnopharmcol, 2007, 109, 151

11. Nagappa A N, Thakurdesai $\mathrm{P}$ A, Rao N V, Singh J, Antidiabetic activity of Terminalia catappa Linn fruits, J Ethnopharmacol, 2003, 88, 45

12. University Group Diabetes Program, A study of the effect of hypoglycemic agents on vascular complications in patient with adult onset diabetes, section 5, Evaluation of phenformin therapy, Diabetes, 1974, 1, 65.

13. Knatterud G, Klimt C R, Levin M E, Goldner M G, Effect of hypoglycemic agent on vascular complication in patient with adult one onset diabetes, section 3, Mortality and selected non fatal events with insulin treatment. Journal of American Medical Association, 1978, 240, 37. blood; (2) reduced hepatic and renal gluconeogenesis; (3) slowing of glucose absorption from gastrointestinal tract, with increase glucose to lactate conversion by enterocytes; (4) and reduction of plasma glucagon levels ${ }^{(16)}$. Phytochemical studies carried out on the extract revealed the presence of phenol and flavonoids, which have been reported to have a major role in reducing oxidative stress associated with diabetes, which in turn helps the regulation of plasma glucose concentration ${ }^{(17)}$. Flavonoids isolated from different sources have been documented to show anti-hyperglycaemic activity ${ }^{(18)}$. Thus, the significant antidiabetic activity of DLPE extract in our study may be attributed to the presence of flavonoids in the plant. Longer duration studies of Diospyros peregrina and its isolated compound are necessary to develop a potent antidiabetic drug.

\section{ACKNOWLEDGEMENT}

One of author (Pawan kumar) is highly thankful to Dr. P.B. Singh, (Research Officer, Botany) Regional Research Institute (Ayurveda) Gwalior Road Jhansi for authenticate plant material. Author is also thankful to NISCAIR New Delhi for literature survey. Aurthor is also thankful to Institute of Pharmacy Bundelkhand University for proving all necessary facility for this research work.

14. Frode T S, Medeiros Y S, Animal models to test drug with pontial antidiabetic activity, J Ethanopharmacol, 2008, 115, 173.

15. Lanter A, Carbohydrates metabolism, abnormalities of post absorptive blood sugar level. In: Clinical Biochemistry, W.B. Sunders and Co. Philodelphia, 1958, 48.

16. Rang $\mathrm{H} \mathrm{P}$, Dale $\mathrm{M} \mathrm{M}$, Ritter $\mathrm{J} \mathrm{M}$, Moore $\mathrm{P} \mathrm{K}$, Pharmacology, Churchill Livingstone, London, 2003, 5, 388.

17. Olmedia N N, Reference values for retinol, tocopherol and main carotenoids in serum of control and insulin dependent diabetic Spanish subject, Clin Chem, 1999, 43, 1066.

18. Minura T, Ichiki H, Hashimto I, Iwamoto N, Kato M, Kubo M, Ishihara E, Komatsu Y, Okada M, Ishida T, Tanigawa K. Anti-diabetic activity of a xanthon compound, mangiferin. Phytomedicine 2001; 8:85-87. 